
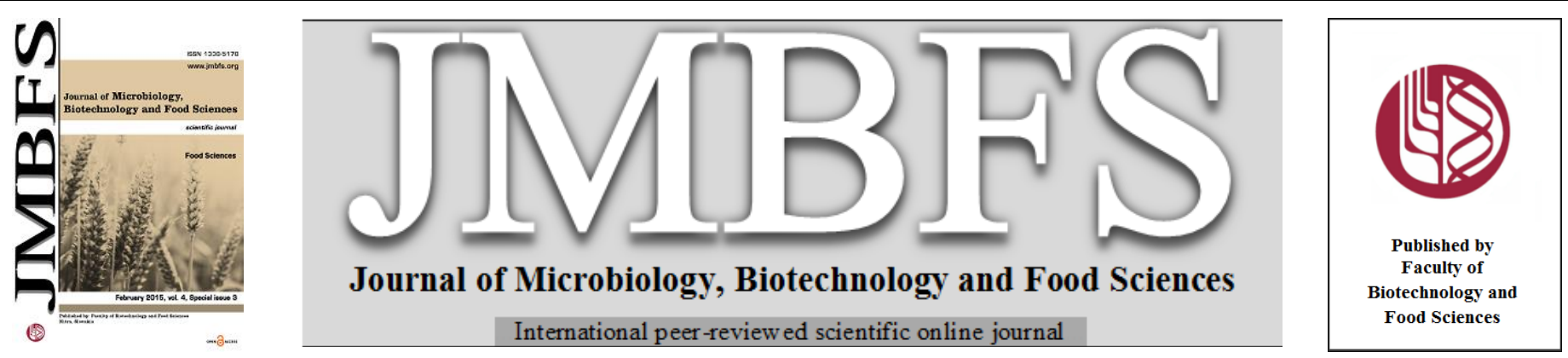

\title{
THE CONTENT OF POLYPHENOLS IN FRUIT OF HIGHBUSH BLUEBERRY (VACCINIUM CORYMBOSUM L.) RELATING TO DIFFERENT FERTILIZER APPLICATION
}

\author{
Michal Medvecký*1, Ján Daniel ${ }^{1}$, Alena Vollmannová ${ }^{2}$,Stanislav Zupka ${ }^{2}$, Miriama Kopernická ${ }^{2}$
}

Address(es): Ing. Michal Medvecký

${ }^{1}$ National Agricultural and Food Center-Grassland and Mountain Agriculture Research Institute Banská Bystrica, Krivá Research Station, Krivá 62, 027 55, Krivá, Slovakia.

${ }^{2}$ Slovak University of Agriculture, Faculty of Biotechnology and Food Sciences, Department of Chemistry, Tr. A. Hlinku 2, 94976 , Nitra, Slovakia.

*Corresponding author: medo.m@post.sk

doi: 10.15414/jmbfs.2015.4.special3.109-1 13

\section{ARTICLE INFO}

Received 29.11.2014

Revised 5. 12. 2014

Accepted 6.12. 2014

Published 2.2.2015

Regular article

open 2 access

\begin{abstract}
Six varieties of high blueberries (Vaccinium corymbosum L.) grown on a plantation of research station in Krivá, that is located in the northern part of Slovakia, was examined to determine the content of polyphenols in the fruit depending on the three variants of fertilization. The first variant was realized with the application of organic fertilization, second one with mineral fertilizers and third variant was left without fertilization. The content of total polyphenols (TP) was determined spectrophotometrically using FolinCiocalteau reagent. The total polyphenol content ranged from $2522.90 \mathrm{mg} \cdot \mathrm{kg}^{-1}$ to $4960.20 \mathrm{mg} \cdot \mathrm{kg}^{-1}$ in the variant with organic fertilization. In the variant with mineral fertilization the total polyphenol content ranged from $2278.25 \mathrm{mg} . \mathrm{kg}^{-1}$ to $3350.23 \mathrm{mg} \cdot \mathrm{kg}^{-1}$. In the variant without fertilization was concentration of total polyphenols from $2503.63 \mathrm{mg} \cdot \mathrm{kg}^{-1}$ to $3790.48 \mathrm{mg} \cdot \mathrm{kg}^{-1}$. Statistical evaluation of the results confirmed a very weak correlation bet ween polyphenols and one variety of different fertilization on the level of significance $(\mathrm{p}<0.05)$. Statistically significant effect on the level of significance $(\mathrm{p}<0.05)$ in Tukey's test was confirmed at the Patriot variety of organic and mineral fertilization and the mineral fertilization and control variant.
\end{abstract}

Keywords: cultivars, blueberry, polyphenol, organic fertilizer, mineral fertilizer

\section{INTRODUCTION}

The fruits of blueberries have very positive effects on the human body Characteristic of these fruits are their bioactive properties. They are an important source of polyphenolic compounds, flavonoids, especially anthocyanins and having high antioxidant activity. On the content of bioactive substances affect several fact ors, such as environmental conditions, degree of ripeness, variety, method of storage and processing

Polyphenols and phenol compounds represent one of the most numerous and most represented groups of plant metabolites and form part of the human diet They are products of secondary metabolism of plants (Mandelová, 2005). Plant polyphenols are substances widespread in almost all plants, particularly in the leaves, flowers, seeds, fruits, and in pathology departments, as well as in products of plant origin (honey, propolis, wine). One group of polyphenols includes a wide and diverse range of compounds - from simple phenolic acids to high polymerized tannins. More than 8.000 phenolic compounds are known, but only a few hundred are identified in the edible parts of plants (Timoracká et al., 2008). Very bright colored fruit is an important source of polyphenolic substances. More than 4.000 polyphenols were identified in large amounts in products such as red wine and green tea, but also in the grapes, apples, onions and wild berries (Béliveaua et al., 2007). Polyphenolic substances contained in foods of plant origin are intensively monitored plant components at present. Their impact on human health is discussed for professional and general level, the views of their operation are not fully uniform (Vollmannová et al., 2008). The content of phenolic compounds in natural materials is quite variable, depending on each type of crop, but also their varieties. It is genetically conditioned and affected by agronomic and environmental soil and weather conditions (Dre wnowski and Gomez, 2000). Blueberries are one of the richest sources of bioactive substances among fruits and vegetables. Such subst ances include in particular polyphenolic compounds with antioxidant activity. Prior $\boldsymbol{e t}$ al., (1998) consider blueberries as one of the richest sources of antioxidant phytonutrients, while composition and content of phenolic compounds in blueberries have changed in relation to variety, period, as well as to locality of growing (Vinson et al., 2001; Ruel and Couillard, 2007, Giovanelli and Burati, 2009). Blueberries belong to the genus Vaccinium, extended family with more than 200 species of evergreen and deciduous trees in size from dwarf shrubs to trees, shrubs size (Riihinen et al., 2008). Blueberry and cranberry extract to prevent the oxidation of lipids in liposomes and reduce LDL cholesterol (Kalea et al., 2006). Extensive use of fertilizers is one of the causes of environmental degradation in the form of pollution of soil, water and air. These problems have led many developed countries to take measures to prevent or minimize the negative effects of excessive and often irrational application of fertilizers. This is reflected in the development and implementation of the principles of intensive integrated pest management and integrated production. Integrated production has set the maximum limit of fertilizer products to plant protection (Hayden, 2001). Fertilization requirements of blueberries are smaller than other berry crops. In experiments carried out in Poland, the most severe frost damage of the bushes were observed on plots fertilized with $150 \mathrm{~kg} \mathrm{~N} \mathrm{ha}^{-1}$ and the results obtained indicate that the optimal nitrogen dose for highbush blueberry is about 50 -100 kg.ha ${ }^{-1}$ (Smolarz and Mercik, 1989). There have been many reports in literature on fertilization of Vaccinium species (Korcak, 1988; Gough, 1996;). On the other hand studies of comparison of organic and conventional fertilization influence on polyphenols content in various food plants are rare, and there has been little published. The aim of our study was to compare the content of total polyphenols from the fruit of six varieties of high blueberries (Bluejay, Nelson, Bluecrop, Patriot, Berkeley and Brigitta) depending on various methods of fertilization (variant with application of organic fertilization, variants with mineral fertilization and variant without fertilization).

\section{MATERIAL AND METHODS}

The experiments were realised in locality of Orava region in northern Slovakiain cadaster of Krivá. The average annual temperature in the area is $6^{\circ} \mathrm{C}$ and annual rainfall of $900 \mathrm{~mm}$. Experimental station with blueberry cultivars is located on a slope with an inclination of $10^{\circ}$ and north-eastern exposure at an altitude of 634 $\mathrm{m}$. Six cultivars of high blueberries (Vaccinium corymbosum L.) were studied (Tab 1). Fruit samples for analysis were collected in August 2013. 
Table 1 Characteristics of observed highbush blueberry (Vaccinium corymbosum L.) cultivars

\begin{tabular}{ll}
\hline Cultivar & Characteristics \\
\hline Bluejay & $\begin{array}{l}\text { medium early cultivar, bush is weakly to moderately stout, well fertile; fruits are medium-sized and very strong, resistant } \\
\text { to cracking, with a wine sweet taste }\end{array}$ \\
\hline Nelson & $\begin{array}{l}\text { medium late cultivar, bush is upright and strong, suit able for colder areas, very fertile; fruits are very big, light blue and } \\
\text { solid and have an excellent quality }\end{array}$ \\
\hline Bluecrop & medium early cultivar, bush is upright; fruits are very big, light blue with a full taste \\
\hline Patriot & medium early cultivar, very fertile, a moderate growth of plant, fruits are large and strong, unbalanced in size \\
\hline Berkeley & medium late cultivar, bush is sprawling open, fast growing, highly productive, fruits are light blue and large \\
\hline Brigitta & $\begin{array}{l}\text { medium late till late cultivar, bush is upright, very fertile, fruits are medium sized, very firm, light blue, slightly acidic, } \\
\text { fruit can be fresh during a very long time storage }\end{array}$ \\
\hline
\end{tabular}

Three variants of blueberry cultivation were investigated. The first one was cultivation with mineral fertilizers application. The nutrients $(30 \mathrm{~kg} \mathrm{~N}, 10 \mathrm{~kg} \mathrm{P}$ and $30 \mathrm{~kg} \mathrm{~K} . \mathrm{ha}^{-1}$ ) were applied in the spring. Nitrogen dose was divided into three parts (1/3 of the totaldose in the first half of April, 1/3 at the end of May and $1 / 3$ at the end of June). Phosphorus and potassium were applied once in the spring. The second variant of blueberry cultivation was realised with application of Hostickeorganic fertilizer, which was applied in dose $1 \mathrm{~kg}$ per $10 \mathrm{~m}^{2}$ at the beginning of vegetation (in the first half of April) and in dose of $0.8 \mathrm{~kg} \mathrm{per} 10 \mathrm{~m}^{2}$ during vegetation (in the second decade of June) .

Host icke organic fertilizer contains fermented cow and horse manure, crushed and granulated horn and natural guano coming from the droppings of seabirds. It is a purely natural product without addition of industrially produced components cont aining $5 \% \mathrm{~N}, 3.5 \% \mathrm{P}_{2} \mathrm{O}_{5}, 1 \% \mathrm{~K}_{2} \mathrm{O}$ and $0.5 \% \mathrm{MgO}$. The third (control) variant of blueberry cultivation was realised without any fertilization.

The total polyphenol content was estimated using Folin-Ciocalteau reagent (Merck, Germany) according to Lachman et al., (2003). Sample ex tract (0.05 to $1 \mathrm{~mL}$ to the expected polyphenol content), $2.5 \mathrm{~mL}$ Folin-Ciocalteau reagent and
$3-5 \mathrm{~mL}$ distilled $\mathrm{H}_{2} \mathrm{O}$ were added to a $50 \mathrm{~mL}$ flask. After $3 \mathrm{~min}$. $7.5 \mathrm{~mL}$ of $20 \%$ $\mathrm{Na}_{2} \mathrm{CO}_{3}$ (Sigma-Aldrich, USA) were added to the flask and the flask content was diluted to $50 \mathrm{~mL}$ with distilled $\mathrm{H}_{2} \mathrm{O}$. The mixture was incubated for 2 hours at laboratory temperature and the absorbance was measured at $765 \mathrm{~nm}$ on the spectrophotometer Shimadzu 710 (Shimadzu, Japan) against the blank sample. The total polyphenol content was expressed as gallic acid equivalents (GAE) in $\mathrm{mg} / \mathrm{kg}$ FM (fresh matter). Each analysis was done in 6 repetitions.

\section{RESULTS AND DISCUSSION}

Sellappan et al., (2002) in his work represent the total content of polyphenols in blueberries ranging from 2610.95 to $9290.62 \mathrm{mg} \cdot \mathrm{kg}^{-1}$. Found results (T ab 2) are lower (from 2278.25 to $4960.20 \mathrm{mg}^{\mathrm{kg}} \mathrm{kg}^{-1}$ ). Our results correspond with those of Kim et al., (2013), who determined 170.9-434.5 mg GAE/100g FM in fruits of highbush blueberries. Moze et al., (2011) and Rodrigues et al., (2011) determined in blueberries significantly higher TP content (1027-1629 mg GAE/100 g FM and 274.5-694.6 mg GAE/100 g FM respectively).

Table 2 Content of polyphenols ( $\mathrm{mg} \cdot \mathrm{kg}^{-1} \mathrm{FM}$ ) in different variants of treatment in investigated cultivars of highbush blueberries (Vaccinium corymbosum L.)

\begin{tabular}{cccc}
\hline Cultivar & Variant with organicfertilization & Variant with mineral fertilization & Control variant without fertilization \\
\hline Bluejay & $3201.56 \pm 289.15$ & $3244.81 \pm 290.05$ & $3430.21 \pm 308.28$ \\
\hline Nelson & $4960.20 \pm 2118.22$ & $3350.23 \pm 160.24$ & $3790.48 \pm 215.07$ \\
\hline Bluecrop & $2522.90 \pm 176.81$ & $2278.25 \pm 161.46$ & $3145.25 \pm 1004.48$ \\
\hline Patriot & $3046.70 \pm 122.89^{*}$ & $2328.06 \pm 130.08 * *$ & $2943.11 \pm 199.18^{*}$ \\
\hline Berkeley & $3132.85 \pm 172.70$ & $3061.62 \pm 478.05$ & $2861.32 \pm 449.20$ \\
\hline Brigitta & $3010.69 \pm 537.52$ & $2526.9 \pm 142.03$ & $2503.63 \pm 562.47$ \\
\hline Average values \pm standard deviation marked with the same symbol $\left(^{*}\right)$ are a statistically significantly difference $(\mathrm{p}<0.05)$
\end{tabular}

Statistical evaluation of the results confirmed a very weak correlation between polyphenols and one variety of different fertilization on the level of significance $(p<0.05)$. Statistically significant effect on the level of significance $(p<0.05)$ in Tukey's test was confirmed at the Patriot variety of organic and mineral fertilization and the mineral fertilization and control variant. The highest average polyphenol content was determined in cv. (variety) Nelson in the variant with organic fertilization $\left(4960.20 \mathrm{mg} \cdot \mathrm{kg}^{-1}\right)$ and lowest determined average content of polyphenols among all the varieties was found in $\mathrm{cv}$. Bluecrop in the variant with mineral fertilization $\left(2278.25 \mathrm{mg} \cdot \mathrm{kg}^{-1}\right)$.

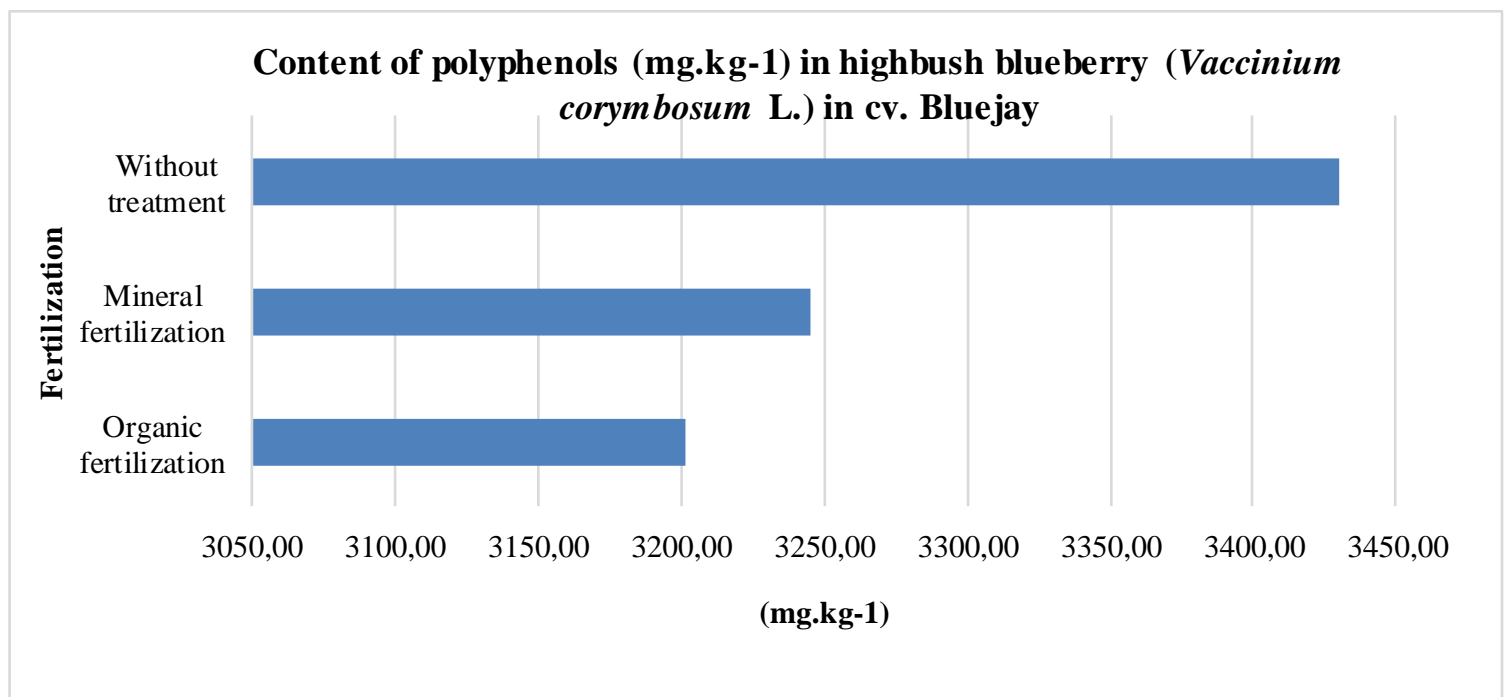

Figure 1 Content of polyphenols $\left(\mathrm{mg}^{\mathrm{kg}} \mathrm{kg}^{-1}\right.$ ) in high blueberry (Vaccinium corymbosum L.) in cv. Bluejay 
The highest average polyphenol content (Figure 1) was determined in a variety Bluejay in the variant without fertilization was $3430.21 \mathrm{mg} \cdot \mathrm{kg}^{-1}$, the lowest in the

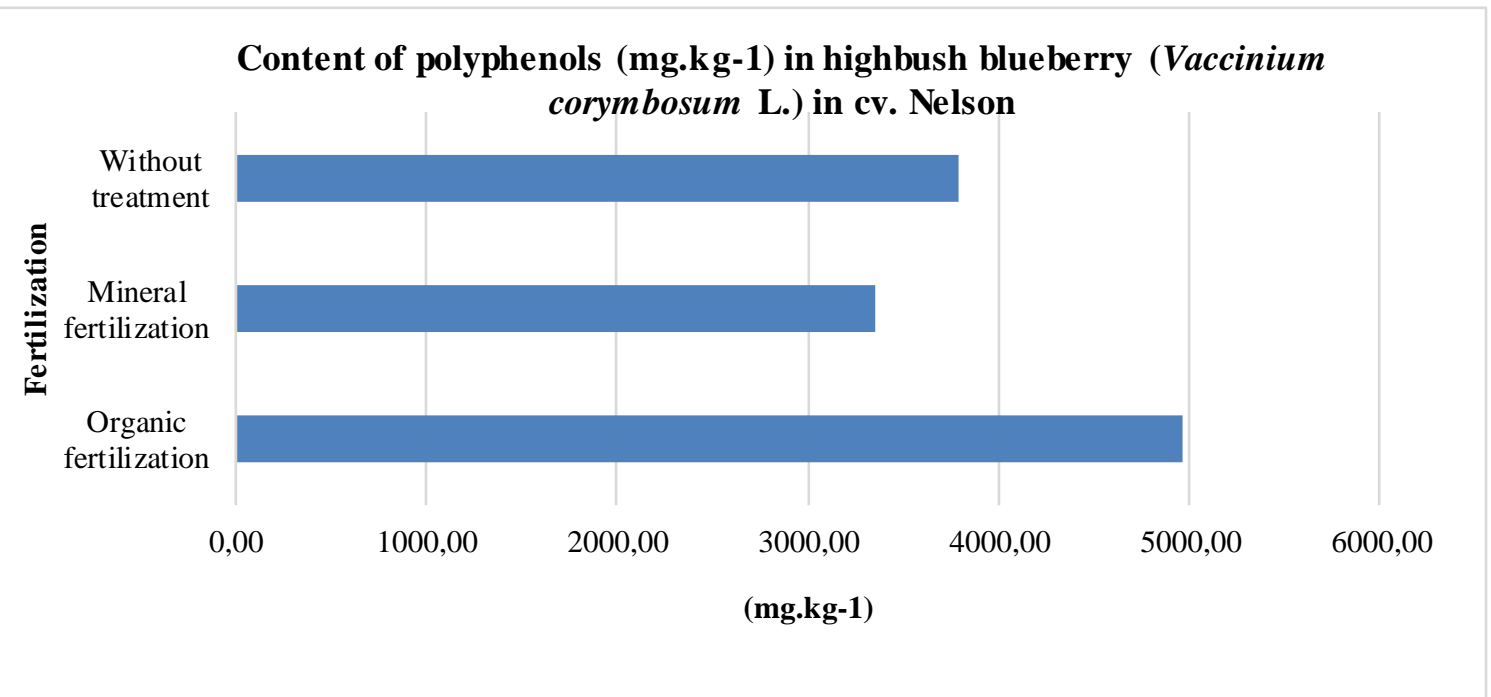

Figure 2 Content of polyphenols $\left(\mathrm{mg}_{\mathrm{kg}}{ }^{-1}\right.$ ) in high blueberry (Vaccinium corymbosum L.) in cv. Nelson

Based on the observed average levels of polyphenols in fruit varieties Nelson (Figure 2) is the order of the investigated variants of fertilization: variant with organic fertilization $\left(4960.20 \mathrm{mg} \cdot \mathrm{kg}^{-1}\right)$, control variant $\left(3790.48 \mathrm{mg} \cdot \mathrm{kg}^{-1}\right)$ and variant with mineral fertilization $\left(3350.23 \mathrm{mg} \cdot \mathrm{kg}^{-1}\right)$.

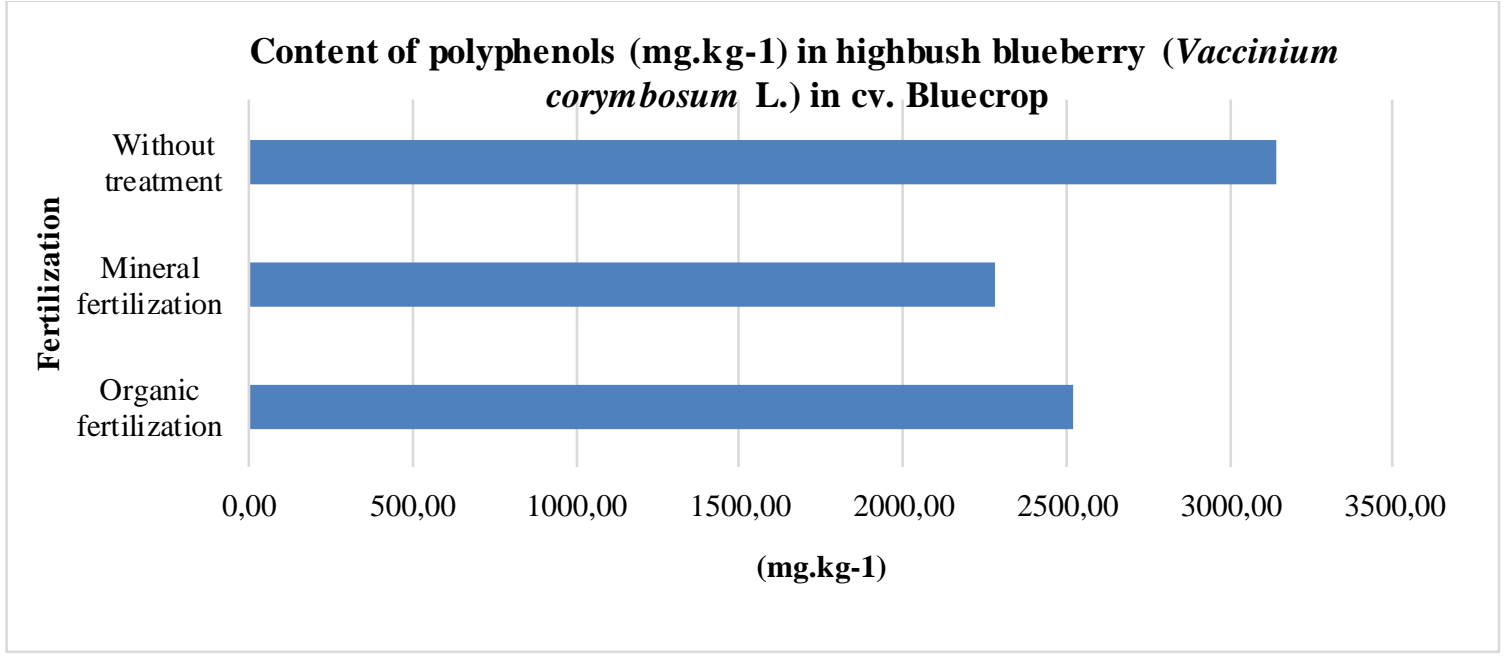

Figure 3 Content of polyphenols $\left(\mathrm{mg}_{\mathrm{kg}} \mathrm{k}^{-1}\right)$ in high blueberry (Vaccinium corymbosum L.) in cv. Bluecrop

The variety Bluecrop (Figure 3), the highest average content of polyphenols found in the variant without fertilization $\left(3145.25 \mathrm{mg} \cdot \mathrm{kg}^{-1}\right)$ and lowest in the variant with mineral fertilization $\left(2278.25 \mathrm{mg} \cdot \mathrm{kg}^{-1}\right)$.

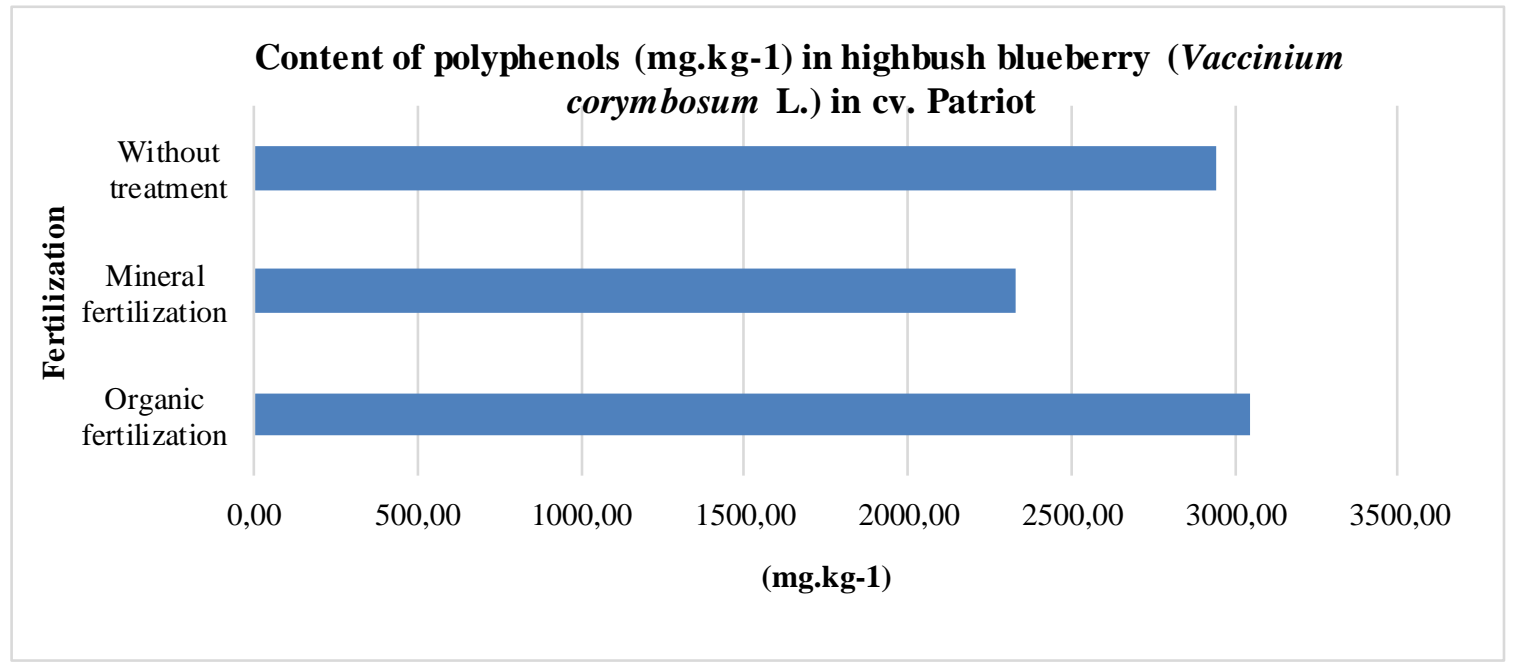

Figure 4 Content of polyphenols $\left(\mathrm{mg}_{\mathrm{kg}}{ }^{-1}\right)$ in high blueberry (Vaccinium corymbosum L.) in cv. Patriot 
The high blueberry fruit variety Patriot (Figure 4) in the variant with organic fertilization was determined by the highest average polyphenol content ( 3046.70 $\left.\mathrm{mg} \cdot \mathrm{kg}^{-1}\right)$, the lowest polyphenol content was found in the variant with mineral fertilization $\left(2328.06 \mathrm{mg} \cdot \mathrm{kg}^{-1}\right)$.

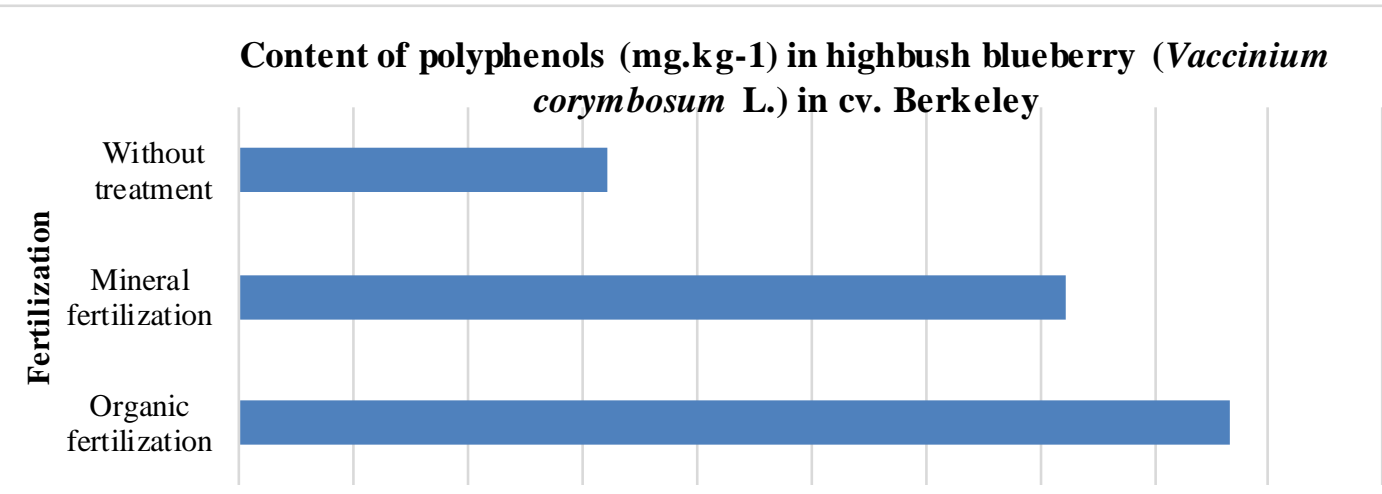

$2700,002750,002800,002850,002900,00 \quad 2950,00 \quad 3000,00 \quad 3050,00 \quad 3100,00 \quad 3150,003200,00$

(mg.kg-1)

Figure 5 Content of polyphenols $\left(\mathrm{mg}^{\mathrm{k}} \mathrm{kg}^{-1}\right.$ ) in high blueberry (Vaccinium corymbosum L.) in cv. Berkeley

The highest average polyphenol content (Figure 5) in Berkeley variety was found in the variant with organic fertilization $\left(3132.85 \mathrm{mg} \cdot \mathrm{kg}^{-1}\right)$, the lowest in the variant without fertilization $\left(2861.32 \mathrm{mg}^{\mathrm{kg}-1}\right)$.

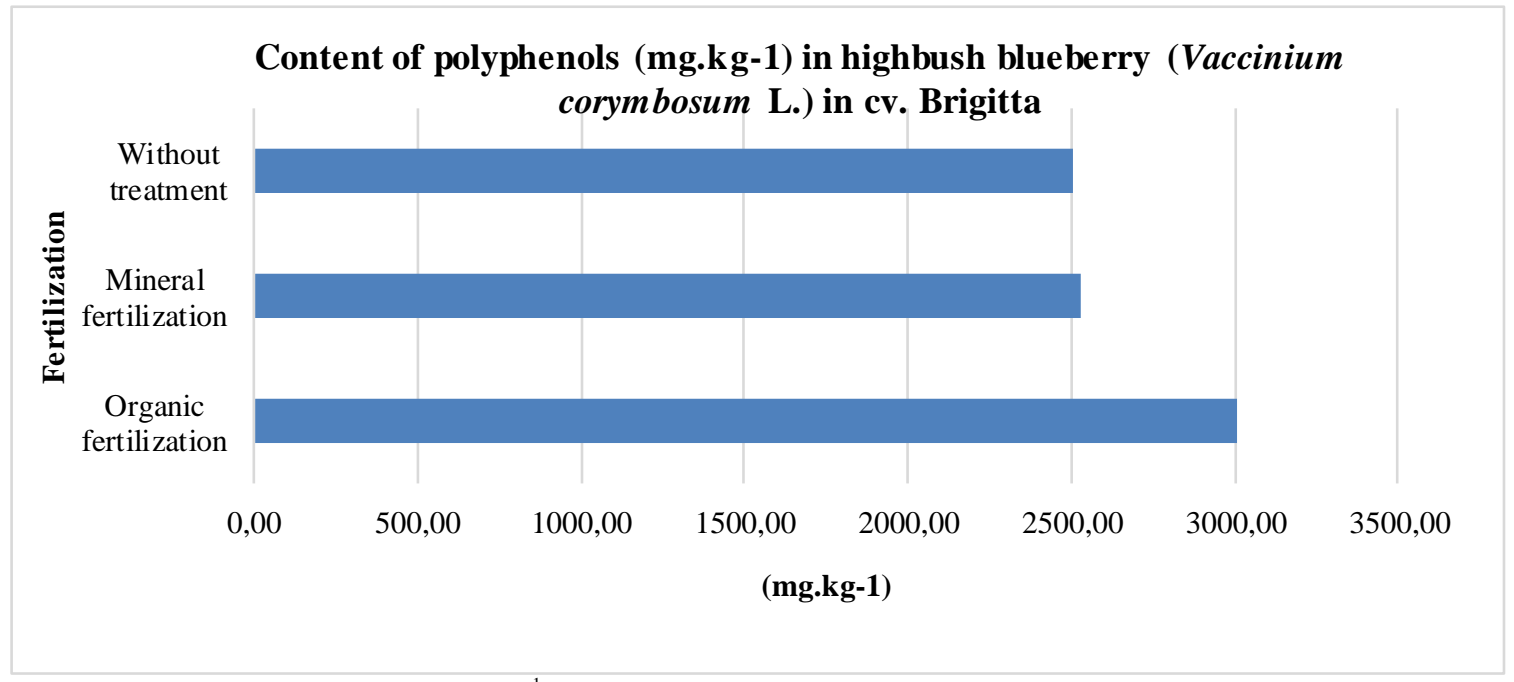

Figure 6 Content of polyphenols ( $\mathrm{mg}^{\mathrm{kg}}{ }^{-1}$ ) in high blueberry (Vaccinium corymbosum L.) in cv. Brigitta

The highest average polyphenol content in a variety Brigitta (Figure 6) was determined in the variant with organic fertilization $\left(3430.21 \mathrm{mg}^{\mathrm{kg}} \mathrm{kg}^{-1}\right)$, the lowest in the variant without fertilization $\left(2503.63 \mathrm{mg} \cdot \mathrm{kg}^{-1}\right)$.

\section{CONCLUSION}

The highest average of polyphenol content of variety with organic fertilizer (OF) was determined in cv. Nelson $\left(4960.20 \mathrm{mg} \cdot \mathrm{kg}^{-1}\right)$ and the lowest determined average content of polyphenols in the OF variant was found in $\mathrm{cv}$. Bluecrop $\left(2522.90 \mathrm{mg} \cdot \mathrm{kg}^{-1}\right)$. The highest average polyphenol content of variety with mineral fertilization (MF) was determined in cv. Nelson (3350.23 mg. $\mathrm{kg}^{-1}$ ) and the lowest determined average content of polyphenols of variety with MF was found in cv. Bluecrop (2278.25 mg. $\left.\mathrm{kg}^{-1}\right)$. The average polyphenol content in the variant without fertilization(WF) was the highest in cv. Nelson (3790.48 mg.kg ${ }^{1}$ ) and the lowest determined average content of polyphenols in the variant with WF was found in cv. Brigitta (2503.63 mg.kg $\left.{ }^{-1}\right)$. From the results we can conclude that the highest average polyphenol content was achieved in the variant with $\mathrm{OF}\left(3312.48 \mathrm{mg} \cdot \mathrm{kg}^{-1}\right)$, followed by variant WF (3112.33 mg.kg $\left.{ }^{-1}\right)$ and the lowest polyphenol content was achieved in the variant with $\mathrm{MF}(2798.31 \mathrm{mg} . \mathrm{kg}$ ${ }^{1}$ ). The results show that the variant has $\mathrm{OF} 6 \%$ higher compared to the average content of polyphenols variant WF, but compared variants based on the MF and WF $11 \%$ higher polyphenol content in the non-fertilized variant. We can only conclude that the polyphenol content is influenced by different methods of fertilization. Our results still could not fully generalize the facts. We used a longlived cult ure. It is necessary a longer period of research that will allow us to make more consistent selection of varieties and verify their utility parameters.
Acknowledgments: The study was supported by project VEGA 1/0308/14 as well as by European Community under project No. 26220220180: Building Research Centre "AgroBioTech".

\section{REFERENCES}

BÉLIVEAU, R., GINGRAS, D. 2007. The role of nutrition in cancer prevention. Canadian Family Physician, 53, 1905 - 1911.

DREWNOWSKI, A., GOMEZ-CARNEROS, C. 2000. Bitter taste, phytonutriens and the consumera review. American Journal of Clinical Nutrition, 79, 727-747. GIOVANELLI G., BURAT TI S. 2009. Comparison of polyphenolic composition and antioxidant activity of wild It alian bluberries and some cultivated varieties. Food Chemistry, 112, 903-908. DOI:10.1016/j.foodchem.2008.06.066 GOUGH, R. E. 1996. Blueberries - North and South. Journal of Small Fruit \& Viticulture, 4, 106-152. DOI:10.1300/J065v04n01_03

HAYDEN, R. A. 2001. Fertilizing blueberries. Purdue University Cooperative Extension Service. Department of Horticulture.

KALEA, A. Z., LAMARI, F. N., THEOCHARIS, A. D. CORDOPAT ISORDOPATIS, P., Schuschke, D. A., Karamanos, N. K., KLIMISZACAS, D. J. 2006. Wild blueberry (Vaccinium angustifolium) consumption affects the composition and structure of gly cosaminoglycans in Sprague-Dawley rat aorta. Journal of Nutritional Biochemistry, 17, 109-116. DOI:10.1016/j.jnutbio.2005.05.015

KIM, J. G., KIM, H. L., KIM, S. J., PARK, K. S. 2013. Fruit quality, anthocyanin and total phenolic contents, and antioxidant activities of 45 
blueberry cultivars grown in Suwon, Korea. Journal of Zhejiang UniversitySCIENCE B (Biomedicine \& Biotechnology), 14, 793. DOI:10.1631/jzus.B1300012

KORCAK, R. F. 1988. Nutrition of blueberry and other calcifuges. Horticultural Reviews, 10, 183-227. DOI: 10.1002/9781118060834.ch6

LACHMAN, J. - HEJT MÁNKOVÁ, A. - DUDJAK, E. et al. 2003. Content polyphenolic antioxidants and phenolcarboxylic acids in selected parts of yacon Vitamins 2003 - Prírodní antioxidantya volné radikály. Pardubice: Univerzita Pardubice, 2003, pp $89-97$. ISBN $80-7194-549-8$.

MANDELOVÁ, L. 2005. Polyfenoly: rozdelení a zdroje v potravě. Výživa a potraviny $60,11-14$.

MOZE, S., POLAK, T., GASPERLIN,L., KORON, D., VANZO, A., ULRIH,

N. P., ABRAM, V. 2011. Phenolics in Slovenian bilberries ( Vaccinium myrtillus L.) and blueberries ( Vaccinium corymbosum L.). Journal of Agricultural and Food Chemistry, 59, 6998. DOI:10.1021/jf200765n

PRIOR R. L., MART IN A.,,SOFIC E., MCEWENJ., O'BRIEN CH.,LISCHNER N., EHLENFELDT M., KALT W., KREWER G. and MAINLAND C.M. 1998 Antioxidant capacity as influenced by total phenolic and anthocyanin content, maturity and variety of Vaccinium species. Journal of Agricultural and Food Chemistry, 46, 2686 - 2693. DOI: 10.1021/jf980145d

RIIHINEN, K., JAAKOLA, L., KÄRENLAMPI, S., HOHTOLA, A. 2008 Organ-specific distribution of phenolic compounds in bilberry (Vaccinium myrtillus) and "northblue" blueberry (Vaccinium corymbosum $x \quad V$ angustifolium). Food chemistry, $110, \quad 156-160$ DOI:10.1016/j.foodchem.2008.01.057
RODRIGUES, E., POERNER, N., ROCKENBACH, II, GONZAGA, LV, MENDES, CR, FET T, R 2011. Phenolic compounds and antioxidant activity of blueberry cultivars grown in Brazil. Food Science and Technology

(Campinas), 31, 911-917

http://dx.doi.org/10.1590/S0101-20612011000400013

RUEL, G., COUILLARD, CH. 2007. Evidences of the cardioprotective potencial of fruits: The case of cranberries. Molecular Nutrition and Food Research, 51, 692-701. DOI: 10.1002/mnfr.200600286

SELLAPAN, S., AKOH, C. C., KREWER, G. 2002. Phenolic compounds and antioxidant capacity of Georgia-grown blueberries and blackberries. Journal of Agricultural and Food Chemistry, 50, 2432-2438. DOI: 10.1021/jf011097 SMOLARZ, K., MERCIK, S. 1989. Growth and yield of highbush blueberry cv. Bluecrop (Vaccinium corymbosum L.) in relation to the level of nitrogen fertilization. Acta Horticulturae, 241, 171-174.

TIMORACKÁ, M., VOLLMANNOVÁ, A., BAJČAN, D. 2008. Analýza polyfenolických lát ok v rastlinnom materiáli. Šumperk: Qualitfood, roč. 8, 2008 č. 2, 2008, s. 14-17. ISSN 1213-6859.

VINSON, J. A., SU, X., ZUBIK, L., BOSE, P. 2001. Phenol antioxidant quantity and quality in foods: Fruits. Journal of Agricultural and Food Chemistry, 49, 2001, 5315-5321.

VOLLMANNOVÁ, A., TÓTH, T., BYST RICKÁ, J., URMINSKÁ, D. 2008. Polyfenolickélátky vybraných pseudocereálií vo vzt'ahu k ich obsahu bielkovín a metalickej zát’aži pôdy. Proteiny 2008. Sborník příspěvků V. ročníku mezinárodní konference. Zlín, 2008. pp. 227- 230, ISBN 978-80-7318-706-4. 